\title{
Staurosporine-induced apoptosis of HPV positive and negative human cervical cancer cells from different points in the cell cycle
}

\author{
B Bernard ${ }^{1}$, T Fest $^{1,2}$, J-L Prétet ${ }^{1}$ and C Mougin*,1 \\ ${ }^{1}$ Laboratoire de Biologie cellulaire et Virale, Faculté de Médecine et de \\ Pharmacie, Place Saint-Jacques, Besançon Cedex, 25030, France \\ 2 Service d'Hématologie, Hôpital Jean Minjoz, Boulevard Fleming, Besançon \\ Cedex, 25030, France \\ * Corresponding author: C Mougin, Laboratoire de Biologie cellulaire et Virale, \\ Faculté de Médecine et de Pharmacie, Place Saint-Jacques, Besançon Cedex, \\ 25030, France. Tel: $33.3 .81 .21 .91 .11 ; 33.3 .81 .66 .56 .95$; \\ E-mail: christiane.mougin@ufc-chu.univ-fcomte.fr
}

Received 12.6.00; revised 7.9.00; accepted 18.10.00

Edited by JM Hardwick

\begin{abstract}
In the present study, we compare the sensitivity of CaSki and HeLa cells (HPV positive, wild-type p53) and C33A cells (HPV negative, mutated $\mathrm{p53}$ ) to a protein kinase inhibitor, the staurosporine (ST). We show that ST can reversibly arrest the three cervical-derived cell lines, either in G1 or in G2/M. Beyond certain ST concentrations or/and over 24 h exposure, the cells underwent apoptosis. This process took place in G1 and G2/M for C33A and CaSki plus HeLa cell lines, respectively. By using an in vitro cell-free system, we demonstrated that cytoplasmic extracts from apoptotic cells were sufficient to induce hallmarks of programmed cell death on isolated nuclei. Moreover, we found that only G2/M cytoplasmic extracts from viable CaSki and HeLa cells supplemented with $\mathrm{ST}$, triggered apoptosis while exclusively G1 cytoplasmic fractions from C33A cells were efficient. Our study describes a possible involvement of the HPV infection or/and p53 status in this different ST-induced apoptosis susceptibility. Cell Death and Differentiation (2001) 8, 234-244.
\end{abstract}

Keywords: staurosporine; G1 and G2/M checkpoints; apoptosis; cell-free system; HPV; cervical cancer cells

Abbreviations: ATP, adenosine 5'-triphosphate; CGP 41251, 4'- $N$ benzoyl staurosporine; DAPI, 4,6-diamidino-2-phenylindole; DB, dilution buffer; DFF45, DNA-fragmenting factor 45; DTT, dithiothreitol; EB, extraction buffer; EDTA, ethylenediaminetetraacetic acid; EGTA, ethylene glycol-bis( $\beta$-aminoethyl ether); FB, freezing buffer, FITC, fluorescein isothiocyanate; HEPES, 4-(2-hydroxyethyl)-1-piperazineethanesulfonic; HPV, human papillomavirus; $\mathrm{IP}$, iodide propidium; $\mathrm{KCl}$, potassium chloride; $\mathrm{MgCl}_{2}$, magnesium chloride; $\mathrm{NaCl}$, sodium chloride; $\mathrm{NB}$, nuclei buffer; $\mathrm{p53}^{\mathrm{wt}}$, wild-type p53; p53 ${ }^{\mathrm{m}}$, mutated p53; PBS, phosphate buffer saline; PIPES, piperazine-N,N'-bis(2-ethanesulfonic acid); PMSF, phenylmethylsulfonyl fluoride; ST, staurosporine; UCN-01, 7-hydroxystaurosporine; TUNEL, TdT-mediated dUTP nick end labeling

\section{Introduction}

Infection with oncogenic human papillomavirus (HPV) types, especially HPV 16 and HPV 18, has been recognized as the major cause of cervical dysplasia and carcinoma. ${ }^{1-3}$ Indeed, the tumors as well as tumor-derived cell lines, CaSki and HeLa cells that harbor respectively HPV 16 and 18 strains, continue to express E6 and E7 viral oncoproteins. ${ }^{4}$ In vitro studies have shown that E6 protein is able to form stable complexes with the wild-type p53 protein and this binding promotes its degradation via the ubiquitin pathway. ${ }^{5,6}$ The E7 protein interacts with the retinoblastoma protein, the $\mathrm{p} 105^{\mathrm{Rb}}$, and turns off its suppressor function. ${ }^{7}$ In the HPV-negative cervical carcinoma cell lines, such as C33A, the two proteins p53 and $\mathrm{p} 105^{\mathrm{Rb}}$ are also involved in the transformation process through mutations. ${ }^{8}$ As a consequence, inactivation and subsequent loss of cell cycle regulation as well as apoptosis-inducing activities are suppressed. It was especially confirmed that transformed fibroblasts expressing HPV 16 or HPV 18 E6 loose the G1 checkpoint activity very early. ${ }^{9}$ The $\mathrm{G} 2$ checkpoint function is also attenuated and this may be related to the ablation of a p53-regulated G2/M checkpoint (reviewed $\mathrm{in}^{10}$ ). Moreover, HPV 18 E6 abolishes p53mediated apoptosis ${ }^{11}$ which normally modulates the cytotoxicity of anticancer agents. ${ }^{12}$

Staurosporine (ST), a potent inhibitor of multiple protein kinases, has been identified as an anti-proliferative drug through its cell growth inhibitory capacities. Indeed, ST enhances differentiation of human promyelocytic leukemia cells, ${ }^{13}$ inhibits tumor cell invasion, ${ }^{14}$ and arrests cell cycle progression. ${ }^{15}$ Low concentrations of ST $(\sim 10 \mathrm{nM})$ lead to G1 cell cycle accumulation. ${ }^{16}$ In contrast, higher concentrations exert a preferential G2/M arrest and/or DNA polyploïdy ( $\sim 50 \mathrm{nM}){ }^{17,18}$ Tumor cell lines seem to require higher doses of ST in order to stop the cells either in G1 or $\mathrm{G} 2 / \mathrm{M}$, in comparison with non transformed cells. ${ }^{15,19}$

Many reports have also confirmed that staurosporine has the potential to kill various human cell lines. ${ }^{20-23}$ Therefore, synthetic analogs of ST have been developed like UCN-01 (7-hydroxystaurosporine) and CGP 41251 (4'-Nbenzoyl staurosporine), that are now used as anti-cancer agents in phase I clinical trials. ${ }^{24,25}$ However, the molecular pathways to achieve tumor suppression remain unclear.

Recent cell-free systems permit to explore apoptotic cell death processes. ${ }^{26-29}$ With these models, it was confirmed that cytoplasmic extracts can induce apoptotic changes in nuclei from a wide variety of human and animal cells. ${ }^{26,27,29,30-32}$ Such in vitro systems give several advantages for morphological and biochemical analysis of apoptotic death pathways. Indeed, apoptosis is presented as a three stage process: an initiation phase followed by an integration phase and finally an irreversible execution 
phase (reviewed $\mathrm{in}^{33}$ ). The latter one begins with condensation of chromatin at the nuclear periphery, followed by blebbing of the nuclear and cytoplasmic membranes. It culminates within $1 \mathrm{~h}$ or so, with a fragmentation of residual nuclear structures into discrete membrane-bounded apoptotic bodies. ${ }^{26,34-36}$ However, whether cell death triggered by specific cellular molecules depends on the cell's position in the ongoing cell cycle is unclear. Growing cells can be synchronized and the use of nuclei from cell populations in specific phases of the cycle in presence of cytoplasmic extracts, from G1, S or G2/M cells, can be a valuable approach to study cell death.

We show that the three cancer cells may either be reversibly blocked in the $\mathrm{G} 1$ or $\mathrm{G} 2 / \mathrm{M}$ phase of the cell cycle, or dye, depending on dose and/or time ST exposure. We observed that cytoplasmic extracts from apoptotic cells are sufficient to initiate events of programmed cell death on healthy nuclei in a cell-free system. Interestingly, we find that nuclei of HPV positive CaSki and HeLa cells enter apoptosis only in the presence of G2/M phase cytoplasmic extracts, while nuclei of HPV negative C33A cells need G1 extracts in order to promote the cell death.

\section{Results \\ ST induces transient and reversible cell-cycle arrest either in $\mathrm{G} 1$ or $\mathbf{G} 2 / \mathrm{M}$}

The cell cycle was investigated by flow cytometry comparing the DNA content of CaSki, HeLa and C33A cells treated with two different ranges of ST for $24 \mathrm{~h}$ (Figure 1). Low concentrations of ST $(2-40 \mathrm{nM})$ led to cell-cycle arrest in G1 (Figure 1A,B). Higher doses of ST (80-140 nM) led to a $\mathrm{G} 2 / \mathrm{M}$ arrest (Figure $1 \mathrm{C}, \mathrm{D}$ ). These results were obtained whatever cells were or not previously synchronized by a double thymidine block (Figure $1 \mathrm{~A}, \mathrm{C}$ versus $\mathrm{B}, \mathrm{D}$ ). Both blocks, G1 and G2/M, started to be observed $12 \mathrm{~h}$ posttreatment (data not shown). After $24 \mathrm{~h}$ of ST exposure, the cells were completely arrested. At this latter time, the two blocks were still reversible when we changed the media and withdrew the staurosporine. As shown in Figure 2 for CaSki cell line, the cells started progressively to recycle reaching step by step the different phases of the cell cycle, as typically synchronized cells (Figure 2A,B). The trypan blue exclusion assay demonstrated that more than $95 \%$ of the cells were viable along all these experiments (data not shown). Moreover, we observed a doubling of cell populations $24 \mathrm{~h}$ after ST removal (Figure $2 \mathrm{C}$ ). Identical results were obtained with HeLa and C33A cell lines.

\section{Long term exposure or high concentrations of ST induce apoptosis}

When the three cervical cancer cells were maintained in the present of ST (2-140 nM) beyond $24 \mathrm{~h}$, they consistently entered in apoptosis. In this context, the results summarized in Table 1 show that a short $(4 \mathrm{~h}$ ) or longer delay (after the $24 \mathrm{~h}$ necessary to get cell synchronization) was required for the three cell lines to enter in programmed cell death, as detected by double labeling Annexin-V/IP. Indeed, the delay was closely dependent on cell lines and cell phase position (Table 1).

In order to further explore the programmed cell death process in our cervical carcinoma cell lines, we treated them with ST concentrations exceeding $140 \mathrm{nM}$. In none synchronized cells after such ST regimens, apoptosis was consistently induced without clear cell-cycle arrests. Nevertheless, when the cells were first blocked in G1 or G2/M, we have been able to show that the entry into cell death started within $4 \mathrm{~h}$ from G2/M for CaSki and HeLa cells, and from $\mathrm{G} 1$ for $\mathrm{C} 33 \mathrm{~A}$ cells (Figure $3 \mathrm{~B}$ ). These results were determined by double labeling Annexin-V/IP and confirmed later by cell cycle analysis, TUNEL assays and timedependent production of internucleosomal DNA ladders (Figure $3 \mathrm{C}-\mathrm{E}$ ). The fluorescence microscopy analysis after DAPI staining revealed characteristic apoptotic nuclear events, such as hypercondensation of the chromatin, reduction of nuclear volume and DNA extrusion through the nuclear envelope (Figure 3F).

These results show that ST-induced apoptosis takes place from different cell cycle phases, according to the HPV status, either from G2/M for HPV positive CaSki and HeLa cells, or from G1 for HPV negative C33A cervical tumoral cells. We decided next to use cell-free approaches in order to confirm this difference.

\section{Cytoplasmic extracts from apoptotic cells promote typical nuclear apoptosis changes independently of the nuclei origins}

We developed a cell-free system to explore cell death in our three cell lines. Purified isolated healthy nuclei have been prepared from $\mathrm{G} 1$ and $\mathrm{G} 2 / \mathrm{M}$ arrested cells initially treated with ST (20 and $100 \mathrm{nM}$, respectively for $24 \mathrm{~h}$ ). Double thymidineblocked cells allowed us to prepare S-phase nuclei. Cytoplasmic extracts were obtained from ST-induced apoptotic cells (200 nM for 36 h) (Figure 4A). After incubation of the cytoplasmic extracts with various types of isolated healthy nuclei, we observed typical apoptotic morphological changes, accompanied by a DNA fragmentation as revealed by TUNEL analysis and agarose gel electrophoresis (Figure $4 B, C)$. This occurred within the first $60 \mathrm{~min}$ at $37^{\circ} \mathrm{C}$ with a chromatin condensation around the nuclear periphery (Figure 4B: 20, 40 min, white arrows) accompanied by nuclear size reduction (Figure 4B: $40 \mathrm{~min}$ ). The DNA was highly condensed against the margins of the nuclei, which retained only an amorphous fibrillar network throughout their interior. ${ }^{30}$ Later there appeared the process of DNA extrusion without nuclear membrane dislocation (Figure 4B: $60 \mathrm{~min}$, white arrows). These changes were identical to those described during programmed cell death occurring in whole cells (Figure 3F). A slight difference may however be noticed between the nuclear morphology in whole cells and in the cell-free system. Nuclei typically appeared more spherical in isolated nuclei incubated in the presence of apoptotic extracts than in nuclei from whole cells (Figure 4B, 40 min versus Figure 3F, 2 min). This could be linked to the presence of a supporting cytoplasmic matrix surrounding the nucleus in intact cells.

The apoptotic process was extremely efficient since $95 \%$ of the healthy nuclei presented structural modifica- 
S-Synchronous cells +20 nM ST $24 h$
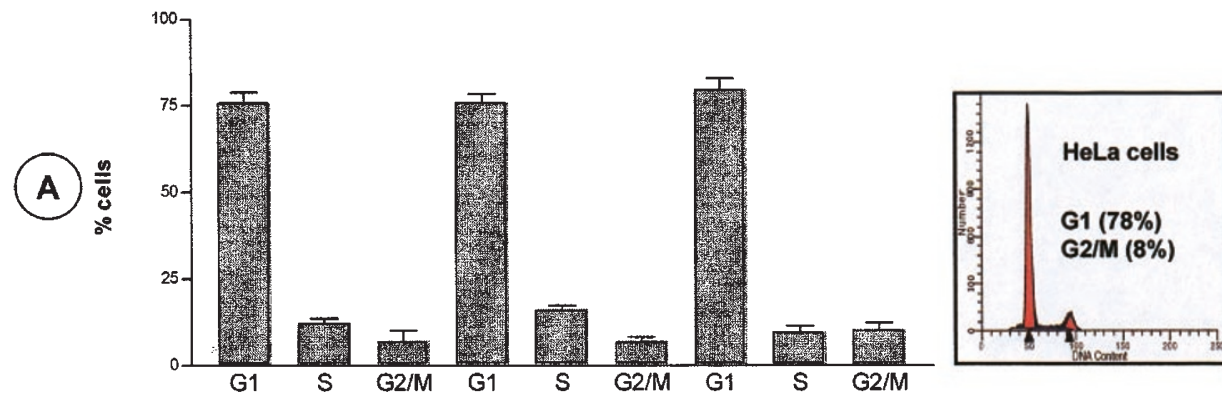

Cell number

Asynchronous cells + 20 nM ST $24 h$
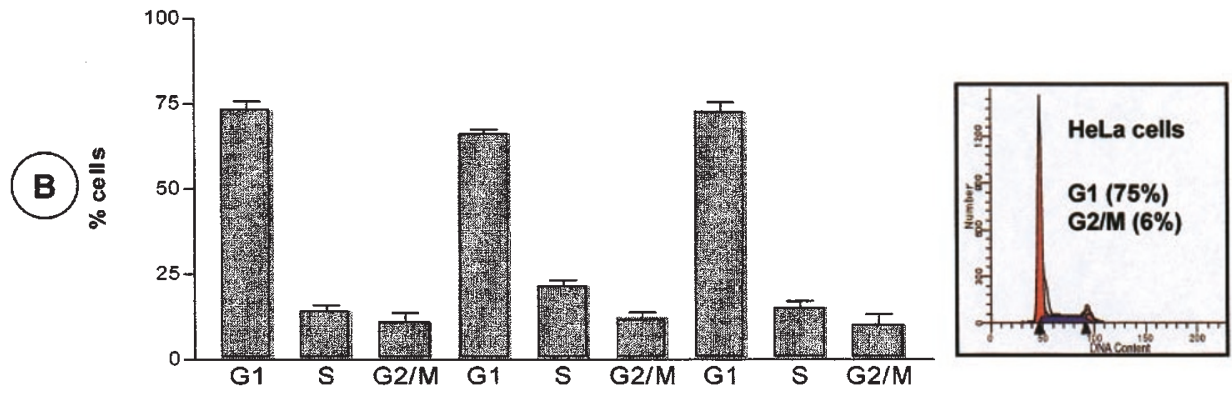

S-Synchronous cells $+100 \mathrm{nM}$ ST $24 \mathrm{~h}$

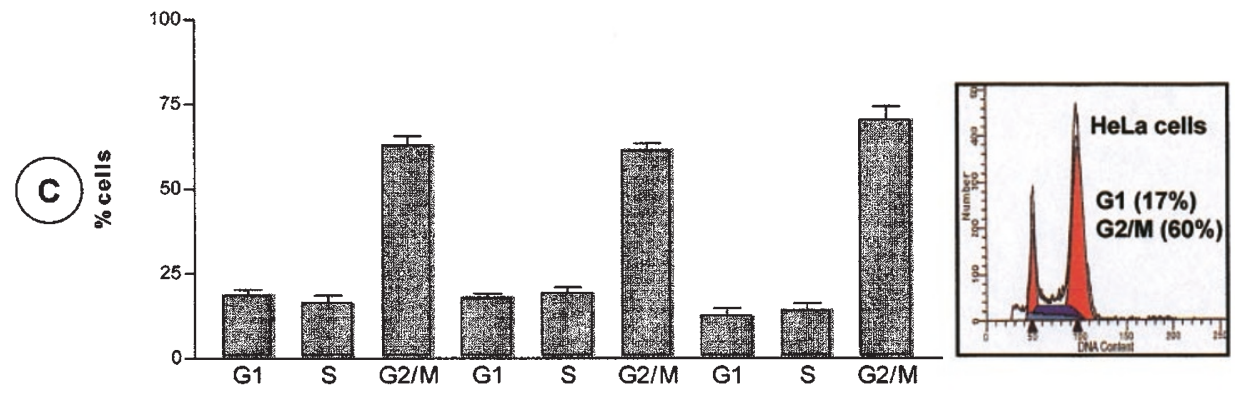

Asynchronous cells + $100 \mathrm{nM}$ ST $24 \mathrm{~h}$

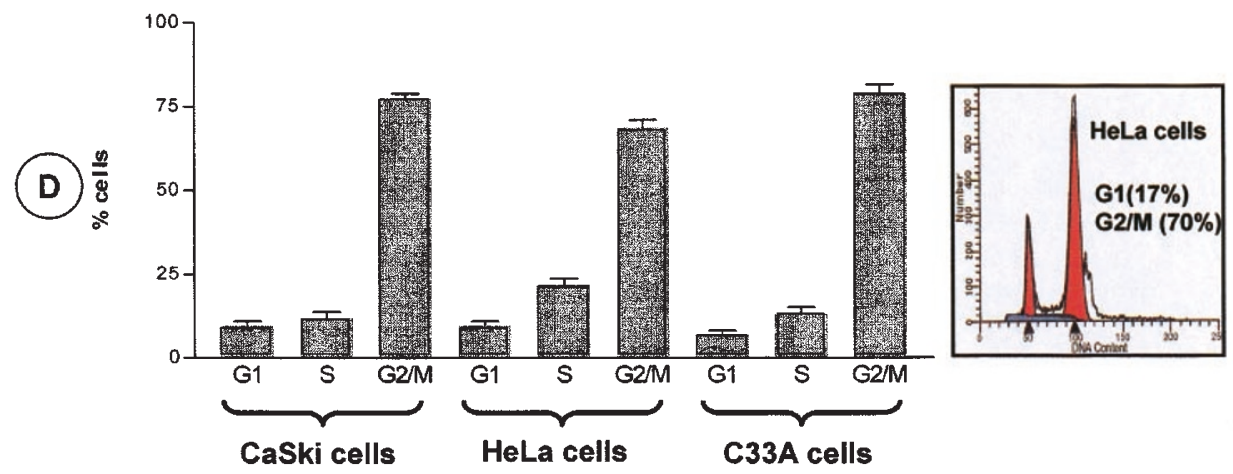

Figure $1 \mathrm{G} 1$ or G2/M arrest of cervical cancer-derived cell lines after treatment by ST for $24 \mathrm{~h}$. Cells were either S-presynchronized (A,C) or not (B,D), and treated with $20 \mathrm{nM} \mathrm{ST}(\mathbf{A}, \mathbf{B})$ or $100 \mathrm{nM} \mathrm{ST}(\mathbf{C}, \mathbf{D})$ for up to $24 \mathrm{~h}$. The cells were stained with propidium iodide and DNA content was determined using flow cytometry $(\mathbf{A}-\mathbf{D})$; the numbers indicate the percentage of cells in G1 and G2/M. The right panels show a representative DNA content obtained from HeLa cells. On left, each histogram and bar represent the mean and standard deviation of triplicate measurements

tions in a synchronous manner in our cell-free assay. This process was blocked at $4^{\circ} \mathrm{C}$ even after $3 \mathrm{~h}$ incubation and did not appear when nuclei were incubated either in presence of the dilution buffer alone or with cytoplasmic extracts obtained from non apoptotic cells (data not shown). 


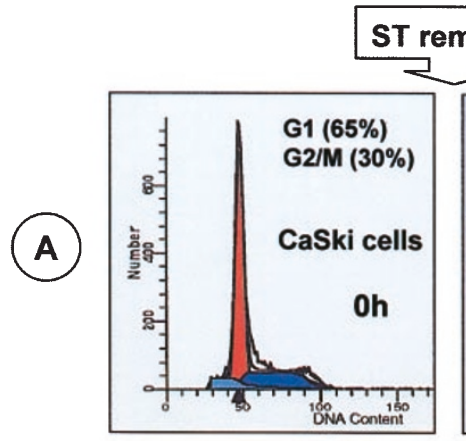

T removal 2
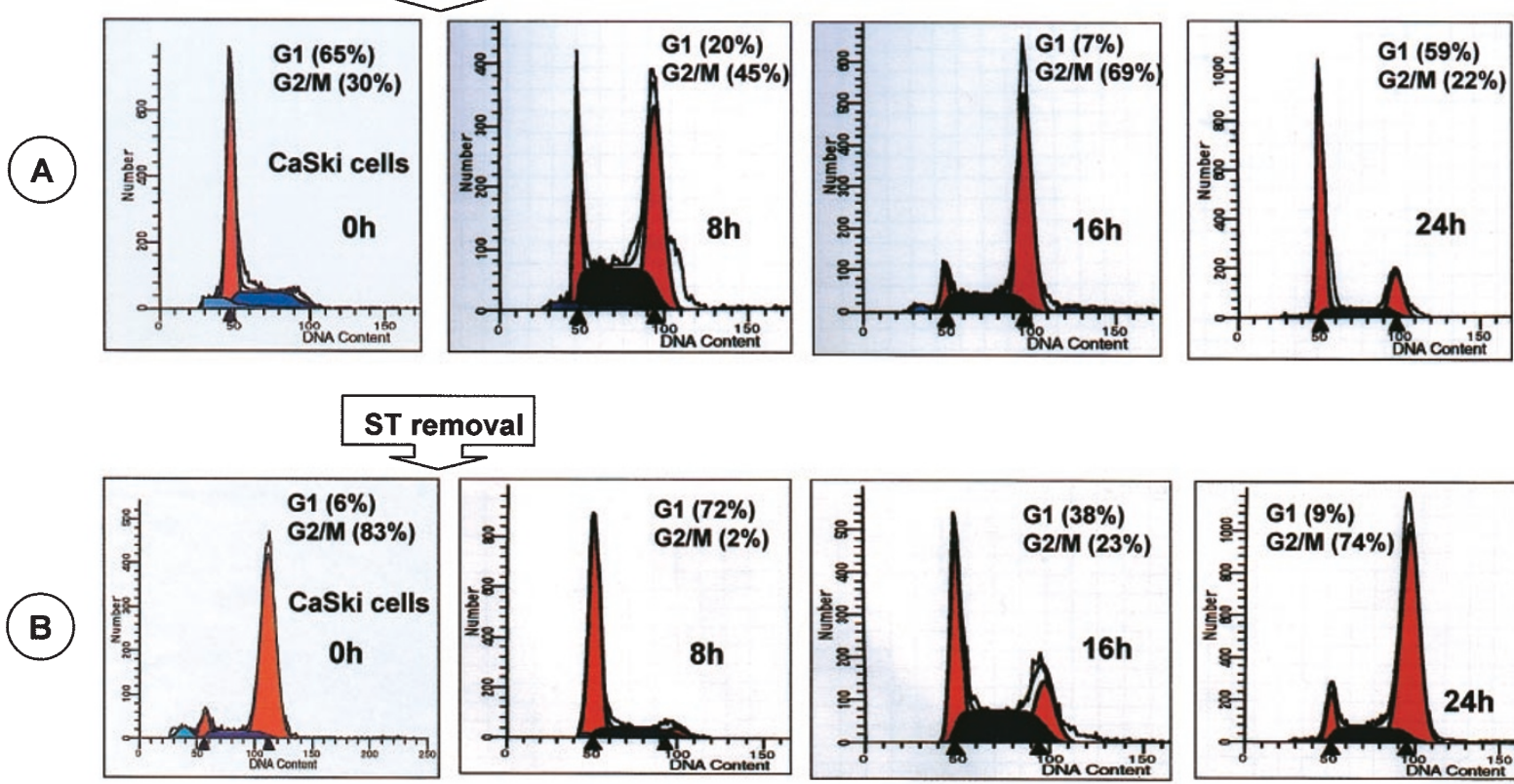

ST removal
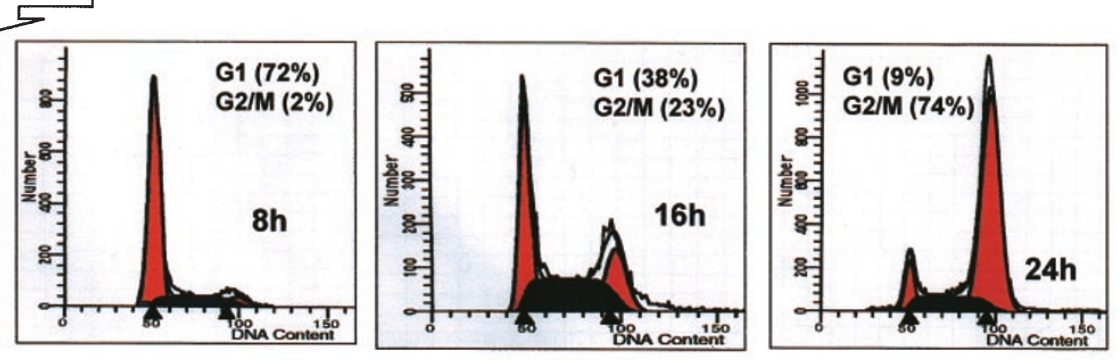

Caski cells

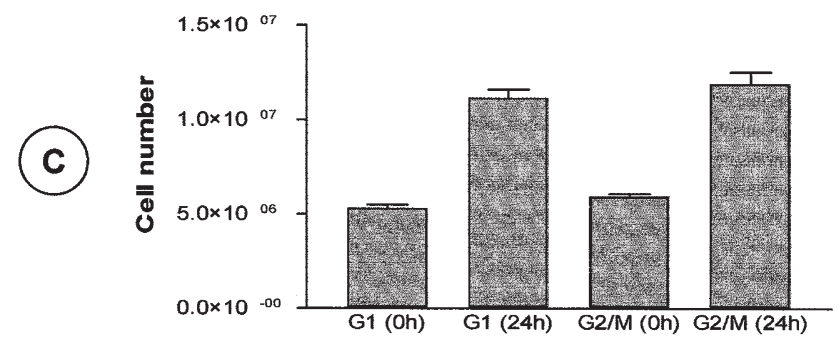

Figure 2 ST removal allowed the cells to restart in the cell cycle. The results of DNA content in CaSki cells, arrested either in G1 (A) or G2/M (B) after $20 \mathrm{nM}$ or $100 \mathrm{nM}$ of ST treatment respectively, were obtained at $0,8,16$ and $24 \mathrm{~h}$ after cells were washed and released into fresh medium. At indicated times, cells were harvested for propidium iodide staining, and analyzed by flow cytometry. In (C) the histograms present the mean of viable cells after ST removal, and bars indicate the standard deviation of triplicate measurements. Cell viability was determined by trypan blue exclusion assay

\section{Apoptosis induction is dependent on the origin of the cytoplasmic extracts with a clear difference between HPV positive and negative cell lines}

Since we demonstrated a difference for entrance into apoptosis between CaSki, HeLa and C33A cells without nuclear involvement, we decided to look for a likely cytoplasmic implication. G1, S and G2/M cytoplasms and nuclei were extracted from synchronized viable cells as described above. Each cytoplasmic extract was incubated with different isolated nuclei for $60 \mathrm{~min}$ at $37^{\circ} \mathrm{C}$. No typical changes related to apoptosis have been noticed in the different combinations that we explored (Table 2). The addition of pro-apoptotic dose of ST (200 nM) in our cellfree system allowed us to find a difference between cells according to the cell cycle origin of the cytoplasmic extracts. Thus, we demonstrated that the ST-induced death of CaSki and HeLa nuclei was dictated by cytoplasm which has to be prepared from G2/M cells. In opposite, the nuclei from HPV negative C33A cells were sensitive to ST only in the
Table 1 Determination of the delay before apoptosis entry after ST treatment

\begin{tabular}{|c|c|c|}
\hline $\begin{array}{l}\text { Cell lines } \\
\text { (\% of cells in } \\
\text { cycle phase) }\end{array}$ & $\begin{array}{c}\text { Delay for apoptosis } \\
\text { induction after } 24 \mathrm{~h} \\
\text { ST-block } \\
(>65 \% \text { cells } \\
\left.\text { Annexin- } \mathrm{V}^{+} / \mathrm{IP}^{-}\right)\end{array}$ & $\begin{array}{c}\text { Cell-cycle exit } \\
\text { towards apoptosis } \\
\text { (\% of cells in cycle } \\
\text { phase) }\end{array}$ \\
\hline \multicolumn{3}{|l|}{ CaSki and HeLa } \\
\hline $\begin{array}{l}\text { G1 }(81 \%) \\
\text { G2/M }(69 \%)\end{array}$ & $\begin{array}{r}20 \mathrm{~h} \\
4 \mathrm{~h}\end{array}$ & $\begin{array}{l}\text { G2/M (73\%) } \\
\text { G2/M (66\%) }\end{array}$ \\
\hline \multicolumn{3}{|l|}{ C33A } \\
\hline G1 (78\%) & $4 \mathrm{~h}$ & G1 (72\%) \\
\hline G2/M (68\%) & $12 \mathrm{~h}$ & G1 (65\%) \\
\hline
\end{tabular}

presence of G1 cytoplasmic extracts (Table 2). Moreover, we have been able to promote apoptosis features in CaSki and HeLa nuclei with G1 C33A cytoplasm and vice versa (data not shown). As illustrated in Figure 5 for CaSki and C33A isolated nuclei, the apoptosis process was typical. 


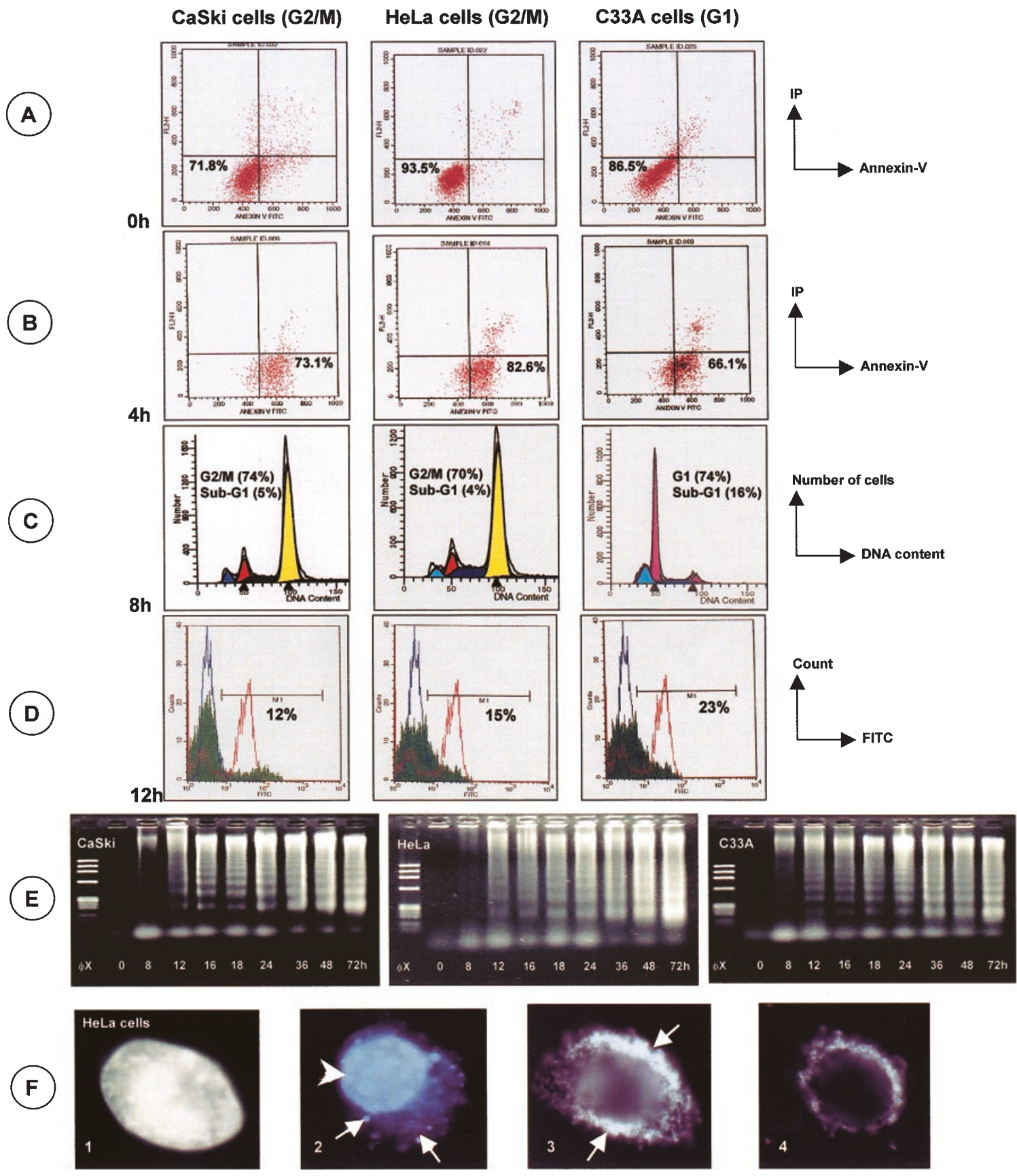

Figure 3 Staurosporine $(150 \mathrm{nM})$ induced apoptosis in G2/M arrested CaSki, HeLa, and G1 arrested C33A cells. Annexin-V labeling, IP staining and TUNEL assay were performed for the three cell lines, at each time point. Most representative data demonstrating induction of apoptosis are shown: Annexin-V labeling 0 and $4 \mathrm{~h}$ post-treatment $(\mathbf{A}, \mathbf{B})$, IP staining $8 \mathrm{~h}(\mathbf{C})$ and TUNEL assay $12 \mathrm{~h}$ (negative control in blue, positive control in red, DNA sample in green) (D). The DNA cleavage was analyzed as oligonucleosome-sized fragments in ethidium bromide-stained agarose gel ( $\phi \mathrm{X}$ : DNA marker $\phi \mathrm{X} 174)$ (E). Apoptosis was confirmed by morphology analysis after DAPI staining under fluorescence microscope following $8 \mathrm{~h}$ exposure to ST. The white arrowhead indicates the condensation of the chromatin, and the white arrows point dense nuclear bodies $(F, \times 400)$

Using the different extracts (Figure $5 \mathrm{~A}$ ) incubated in the presence of $200 \mathrm{nM}$ of ST, we showed characteristic morphological changes (Figure 5C) and internucleosomal DNA fragmentation as well as positive TUNEL analysis (Figure 5D).

In our cell-free system, the S-phase cytoplasm could never provoke apoptotic features in different tested nuclei.
Identically, $200 \mathrm{nM}$ of ST without cytoplasmic extracts did not induce apoptosis (Table 2).

\section{Discussion}

In the present study, we investigated the susceptibility of HPV positive and negative human cervical carcinoma-derived cell 

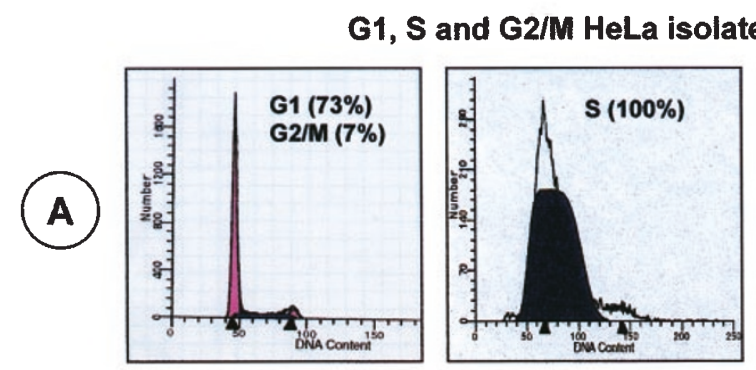

\section{HeLa cells used for preparation of apototic cytoplasmic fractions}
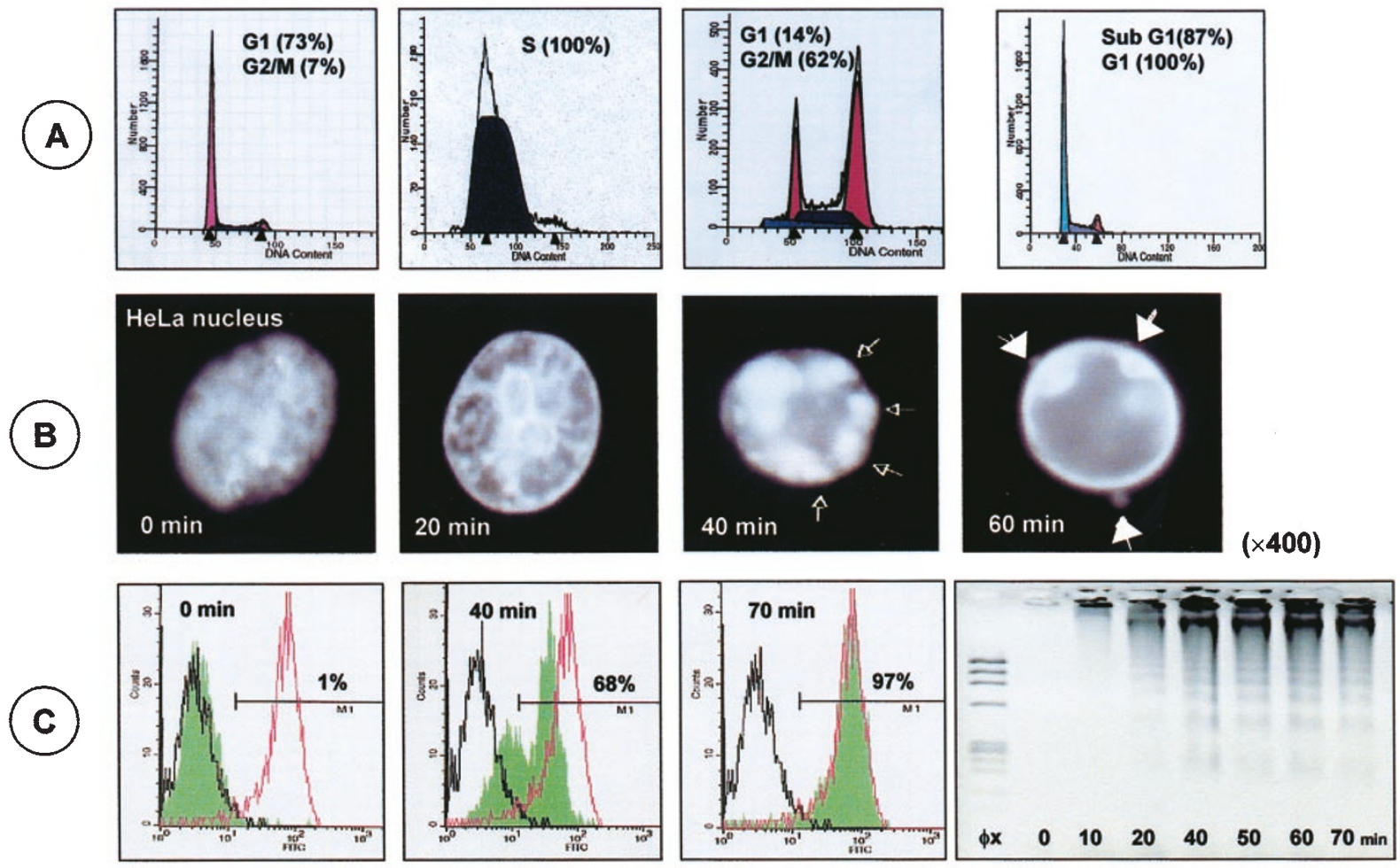

Figure 4 Representative time-course of morphological and biochemical changes obtained in HeLa isolated nuclei upon addition of cytoplasmic extracts from apoptotic cells. Nuclei in G1, S and G2/M phases were incubated with cytoplasmic extracts from apoptotic cells ( $200 \mathrm{nM} \mathrm{ST,} 36 \mathrm{~h}$ ) (A). They were removed at the indicated times $(0,20,40$ and $60 \mathrm{~min})$, and examined under fluorescence microscope at $\times 400$ magnification after DAPI staining. The white arrows indicates the nuclear chromatin condensation $(40 \mathrm{~min})$ and point later the DNA extrusion $(60 \mathrm{~min})(\mathrm{B})$. Time-dependent DNA cleavage was concomitantly observed by TUNEL analysis (negative control in black, positive control in red, DNA sample in green), and gel electrophoresis ( $\phi \mathrm{X}$ : DNA marker $\phi \mathrm{X} 174)$ (C)

Table 2 Comparison of different in vitro cell-free systems

\begin{tabular}{llccc}
\hline & & Source of cytoplasmic & & \\
& Source of nuclei & extracts & ST addition & Apoptosis induction \\
\hline CaSki and HeLa & G1 or S or G2/M cells & G2/M cells & $200 \mathrm{nM}$ & Yes \\
& G1 or S or G2/M cells & G1 cells & $200 \mathrm{nM}$ & No \\
C33A & G1 or S or G2/M cells & G1 cells & $200 \mathrm{nM}$ & Yes \\
& G1 or S or G2/M cells & G2/M cells & $200 \mathrm{nM}$ & No \\
CaSki HeLa and C33A & G1 or S or G2/M cells & G1 or S or G2/M cells & - & No \\
& G1 or S or G2/M cells & No & NM & No \\
& G1 or S or G2/M cells & S cells & $200 \mathrm{nM}$ & Yes \\
\hline
\end{tabular}

lines to react to staurosporine (ST), a member of a new class of drugs active on the cell cycle, and potentially interesting in further anticancer therapeutic strategies. Our results showed that the three tumor cell lines tested were sensitive to ST that induced either cell-cycle arrest or apoptosis. Interestingly, in this latter process we observed a difference in the exit from the cell cycle between HPV positive and negative cell lines, strictly dependent on the cytoplasmic fraction as based on our cell-free system.

Cancer of the uterine cervix remains a public health problem worldwide. The treatment of this disease is based on surgery with or without radiotherapy, whereas che- motherapy is largely recognized as poorly effective. ${ }^{37}$ Human papillomaviruses (HPVs) have been strongly associated with cervical cancer and its precursor lesions. ${ }^{1-3,38-40}$ HPV 16 and 18 genotypes account for greater than $65 \%$ of all HPV DNA-positive invasive cervical carcinomas in multi-institutional studies ${ }^{1,41}$ and are found in the majority of human cervical carcinoma-derived cell lines. ${ }^{42}$ In this context, the intervention of HPV infection in the carcinogenesis is mainly supported by E6 and E7 oncoproteins which abrogate p53 and pRb functions; the genes of those two factors retain usually a wild-type form. ${ }^{43}$ The recent demonstration, that p53 and pRb disruptions are 
Cells used for preparation of cytoplasmic fractions

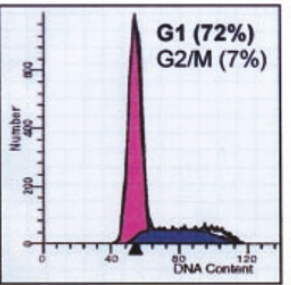

Isolated nuclei

A
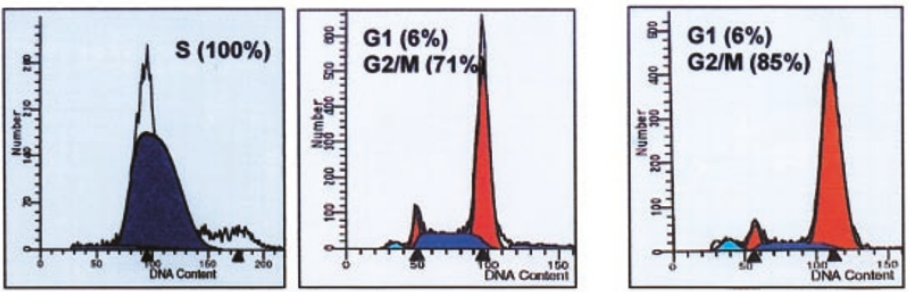

CaSki cells
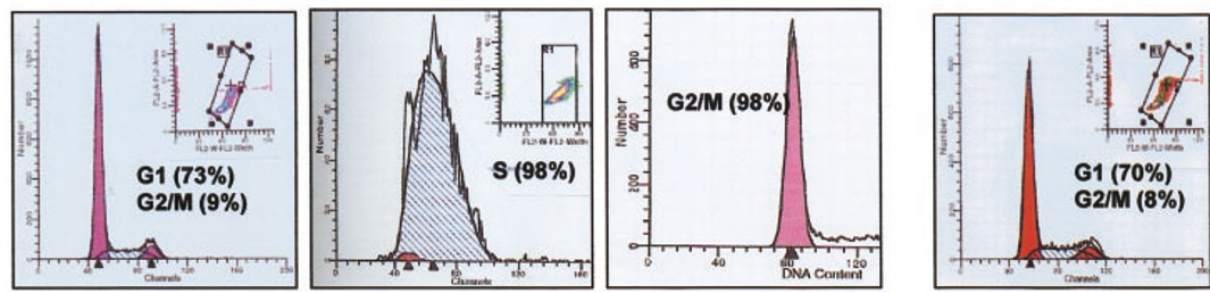

C33A cells
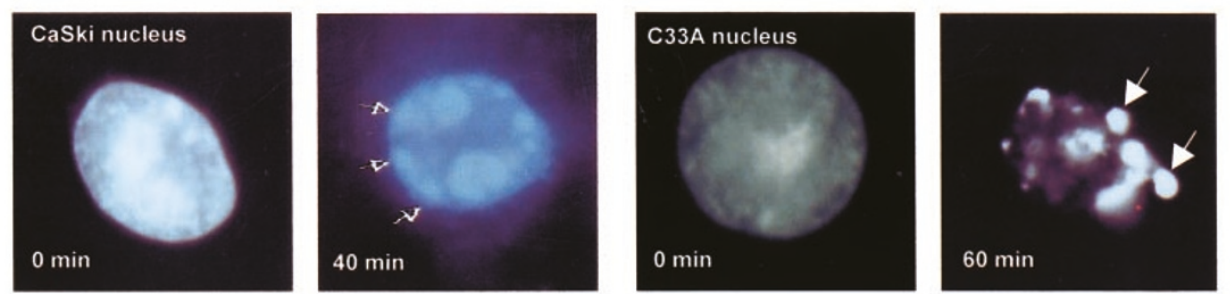

$(\times 400)$
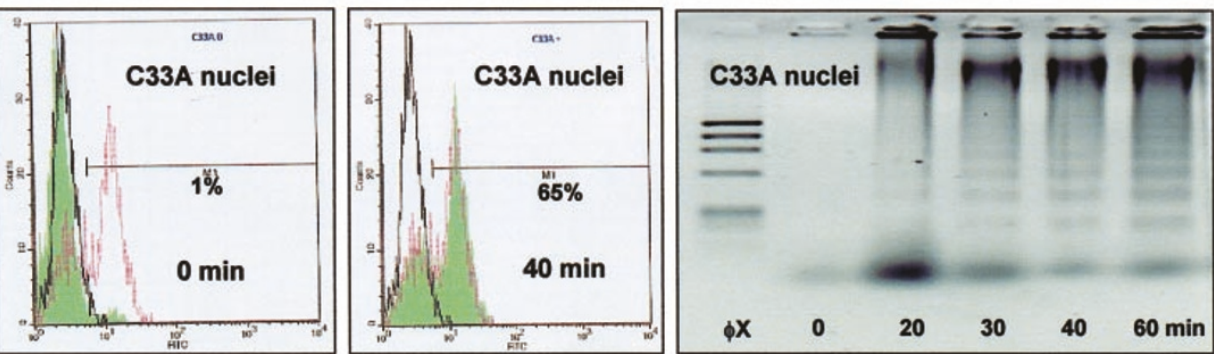

Figure 5 Morphological changes and DNA fragmentation observed in nuclei of either HPV positive or negative cells upon addition of G2/M or G1 phase cytoplasmic extracts, supplemented with $200 \mathrm{nM}$ of ST. G1, S or G2/M phase CaSki and C33A nuclei were incubated respectively with G2/M CaSki and G1 C33A cytoplasmic extracts $(\mathbf{A}, \mathbf{B})$. The apoptotic reaction was performed at $37^{\circ} \mathrm{C}$ for $60 \mathrm{~min}$ in the presence of $200 \mathrm{nM} \mathrm{ST}$. The morphological nucleus observations ( $\times 400$ ), after DAPI staining, was in agreement with results obtained in Figure 4 (C). The increase of DNA cleavage was confirmed by flow cytometry after TUNEL labeling (both left panels), and agarose gel electrophoresis (right panel) (D)

effective in the way to create human tumor cells, contributes to the knowledge of HPV-induced cell transformation. ${ }^{44}$

In order to explore new drugs to treat uterine cervix cancer, we decided to study the responses of three different human cervical carcinoma cell lines under staurosporine exposure. CaSki and HeLa cells were selected for their HPV positive status (types 16 and 18, respectively) associated to a wild-type $\mathrm{p} 53$ and pRb expression. ${ }^{45}$ In contrast, our third tumor cell line (C33A cells) present mutations on both genes without HPV infection. ${ }^{46}$ Two different ranges of ST were tested showing that the three cell lines might be reversibly arrested either in G1 or G2/M cell-cycle phase, depending on the dose and duration of the treatment.

The first range of tested ST drug, 10-40 nM (Figure 1), had the ability to block the cells in G1, as described in a wide variety of normal or transformed mammalian cells, through both CDK2 activity inhibition and CDK inhibitor protein induction such as $\mathrm{p} 21^{\mathrm{CIP} 1 / \mathrm{WAF} 1 / \mathrm{SDI} 1}$ and p27 KIP1.17,19,47-49 Conversely, growth arrest capacity seems to disappear in foreskin keratinocytes transfected and immortalized by the E6/E7 HPV oncoproteins. ${ }^{50}$ Our data suggest that the three long established carcinomaderived cell lines used in the present study retained their original parental sensitivity to ST, as it was recently demonstrated for human cancer cells. ${ }^{51}$ Concerning the G2/M arrest, it was observed with ST doses ranging from 40 to $140 \mathrm{nM}$ (Figure 1). This result is in agreement with previous data obtained in normal and transformed cells $^{15,17,52}$ including the E6/E7 immortalized foreskin keratinocytes. ${ }^{50}$ The mechanism involved in such STinduced G2/M block is related to a reduction of the CDK1/cyclin B kinase activity secondary to a cdc25C phosphatase inactivation. ${ }^{53,54}$ 
Interestingly both $\mathrm{G} 1$ and G2/M cell-cycle arrests were reversible in the first $24 \mathrm{~h}$ allowing cells to be synchronized after staurosporine removal (Figure 2). These data suggest that the ST drug as well as analogs, i.e. UCN-01, might be useful in future anticancer therapeutic strategies. The antiproliferative effects of ST were observed in our study for drug concentrations ranging from 10 to $140 \mathrm{nM}$ and up to a $24 \mathrm{~h}$ treatment duration. Over $140 \mathrm{nM}$ dose or $24 \mathrm{~h}$ of exposure, the ST irreversibly induced apoptosis. The exact mechanism of such apoptosis induction remains elusive which made us decide to use this model as well as a cell free system to approach this question.

Programmed cell death was explored in our study by both morphological and biochemical analysis. By using $150 \mathrm{nM}$ of ST on synchronized cells, we observed in each cell line characteristic morphological signs of apoptosis. These are mainly represented by cell shrinkage and nuclear condensation associated to a blebbing process involving both nuclear and cytoplasmic membranes, that lead to the final fragmentation step producing apoptotic bodies. ${ }^{26,34-36}$ TUNEL assay and visualization of a sub-G1 peak by cellcycle analysis confirmed this final apoptotic event. Interestingly, our cycle study revealed a possible relation between the sub-G1 peak generation and the depletion of CaSki and HeLa cells in the G2/M fraction, and a reduction of C33A cells in the G1 fraction (Figure 3). These results suggested to us that ST-induced apoptosis took place from different cell-cycle positions. The entry in apoptosis occurred from G2/M for CaSki and HeLa cell lines, while it specifically appeared from G1 for C33A cells. In contrast, the three cervical carcinoma-derived cells were resistant to cell death entry from the S-phase after ST treatment.

In order to demonstrate a relationship between cell-cycle exit to apoptosis and the type of cervical cell lines, we decided to develop a cell-free system analysis. This model recapitulates the selective effects observed in intact cells permitting further to analyze the cellular and/or molecular targets involved in specific transduction pathways. The cellfree system turned out to be powerful in the cell cycle research for several years in Xenopus laevis field, ${ }^{55,56}$ and more recently in mammalian cells as shown by Krude et al. ${ }^{57}$ in a HeLa cell-free system. Likewise, we demonstrated that the programmed cell death as described above is under the dependence of the cytoplasm. First, only cytoplasmic extracts from any apoptotic cells were able to induce, whatever the origin of isolated nuclei, specific morphological modifications related to apoptosis (Figure 4). Secondly, we showed that only some specific cytoplasmic fractions originating from viable cells and supplemented with $200 \mathrm{nM}$ pro-apoptotic staurosporine, had the ability to provoke nuclear changes (Figure 5). Thus, apoptosis entry of CaSki and HeLa cells was dependent on cytoplasmic components and specifically related to the G2/M cell-cycle checkpoint (Table 2). In opposite, C33A apoptosis was strictly related to the $\mathrm{G} 1$ phase. Remarkably, this difference between cells could be associated with the HPV status. However, we can not conclude that the effects observed are due solely to HPV, since the $\mathrm{p} 53$ and $\mathrm{p} 105^{\mathrm{Rb}}$ status is also different between the HPV positive and HPV negative cell lines.
Concerning the S-phase exploration, our cell-free model failed to activate apoptosis with any type of S-phase cytoplasmic extracts supplemented with ST. Identical Sphase protective activity has previously been reported in two different apoptosis induction models. Fas-induced apoptosis in $\mathrm{T}$ cells as well as oncogene promotion of cell death in fibroblasts were inefficient in S-phase arrested cells. ${ }^{58,59}$

Our overall results indicate that apoptosis induction takes place in the cytoplasm and is independent of the nucleus issue. This apparently passive role of nuclei in the execution of apoptosis is consistent with previous experiments which found apoptotic changes proceed exclusively in cytoplasm. ${ }^{60-62}$ This latter one presented an ubiquitous apoptosis transduction pathway which might likely be modulated by staurosporine. ${ }^{60,63}$ Such modulation could take place at ST-sensitive components which have to be multiple and different since our results demonstrated that HPV positive cells were exclusively sensitive to cell death in $\mathrm{G} 2 / \mathrm{M}$ phase and HPV negative cells in G1 phase. Additionally to the HPV infection, the three cervical cancer cell lines differ on their p53 gene status besides a supposedly identical p53 function abrogation. Wild-type p53 causes cell-cycle arrest at late G1 phase and induction of apoptosis. ${ }^{64}$ Moreover, p53 will also be required to arrest human cells in G2 after DNA damage. ${ }^{65,66}$ Usually, it is believed that cells with a loss of p53 function present a p53-independent apoptotic sensitivity. ${ }^{12,67}$ Nevertheless, former studies based on HPV positive CaSki and Hela cells after cisplatin treatment showed a clear p53 and p $21^{\text {WAF1 }}$ protein expression leading to the hypothesis that this drug may use a p53-dependent pathway even in the presence of E6 and E7 oncoproteins. ${ }^{68,69}$ Taken together, our data did not rule out the involvement of a p53dependent pathway in the ST-induced apoptosis, independent of the HPV and p53 status. Indeed, it has been recently shown that under some circumstances, the wildtype p53 function of mutant p53 genes may be restored. ${ }^{70}$

In summary, our results showed that staurosporine may reversibly arrest cervical cancer cell lines in G1 or G2/M depending on the concentration and the duration of exposure. Beyond certain ST concentrations or/and over $24 \mathrm{~h}$ exposure, an irreversible apoptotic entry was initiated. We demonstrated that this death process was strictly dependent on the cytoplasm, related to the cell-cycle phase and to the cell lines.

To conclude, the unspecific protein kinase inhibitor staurosporine has an antiproliferative effect by inducing G1 or G2/M arrest, and apoptosis. Further explorations focused on HPV and cell cycle regulatory proteins are important to understand the complicated mechanisms involved in apoptosis. Therefore, staurosporine, or its derivatives, might be useful in the treatment of cervical neoplastic diseases.

\section{Materials and Methods}

\section{Cell cultures and S-phase synchronization}

HPV18-positive HeLa (ATCC CCL 2, Rockville, MD, USA) and HPVnegative C33A (ATCC HTB 31) human cervical cancer-derived cell 
lines were cultured in MEM-Earle medium (Sigma, St Louis, MO, USA), supplemented with $10 \%(\mathrm{v} / \mathrm{v})$ fetal calf serum (Gibco BRL, Cergy Pontoise, France), $60 \mathrm{mg} / \mathrm{l}$ gentamycine, 1\% (v/v) non essential amino acid (Biochrom KG, Berlin, Germany). Five per cent (v/v) sodium pyruvate (Sigma) were added for C33A cells. HPV16-positive CaSki (ATCC CRL 1550) human cervical cancer cell line was grown in RPMI 1640 medium (Sigma) containing 10\% (v/v) fetal calf serum, $60 \mathrm{mg} / \mathrm{ml}$ gentamycine and $1 \%(\mathrm{v} / \mathrm{v})$ non essential amino acid. Carcinoma cell lines were incubated at $37^{\circ} \mathrm{C}$ in a humidified atmosphere of a $5 \%(\mathrm{v} / \mathrm{v}) \mathrm{CO}_{2}$ in air.

For synchronization, $3 \times 10^{5}$ cells were seeded in $100 \times 20 \mathrm{~mm}$ Optilux ${ }^{\circledR}$ petri dish (Becton Dickinson, Plymouth, UK). When they were about $80 \%$ confluent, thymidine was added to a final concentration of $2.5 \mathrm{mM}$. After $25 \mathrm{~h}$ of incubation at $37^{\circ} \mathrm{C}$, cells were released into fresh culture medium and incubated in the usual growth medium for $8 \mathrm{~h}$ to allow cells exiting from S-phase. ${ }^{37}$ After, a second incubation with $1 \mathrm{mM}$ thymidine for $14 \mathrm{~h}$, cells were washed twice with PBS, once with fresh culture medium and used for further experiments.

\section{Staurosporine treatments}

Staurosporine (ST) (Sigma) was dissolved in dimethyl sulfoxide. ST was used on unsynchronized or S-synchronized CaSki, HeLa and C33A cell lines. Dose response and kinetic studies were performed using $2,10,20,30,40,50,80,100,120$ and $140 \mathrm{nM} \mathrm{ST}$ for periods of $4,8,12,16,18$ and $24 \mathrm{~h}$. At this last time point, part of the cells were either maintained in the presence of the same concentration of ST, or washed and released in fresh culture medium for additional periods of $4,8,12,16,24$ and $36 \mathrm{~h}$. Moreover, in other experiments, cell lines were treated with $150,160,180$ and $200 \mathrm{nM}$ for periods of $4,8,12,16$, 18 and $24 \mathrm{~h}$. Cells were analyzed by flow cytometry, and fluorescence microscopy. All the experiments reported here were undertaken at least three times.

\section{Isolated nuclei}

The isolation of interphase nuclei was carried out as previously described. ${ }^{38,39}$ Briefly, $2-5.10^{8}$ cells were harvested by trypsinization $(0.15 \%$ trypsin, $0.015 \%$. EDTA), washed once with cold PBS, and centrifuged for $5 \mathrm{~min}$ at $1600 \times \mathrm{g}$. A second wash was performed in 20 vol of ice-cold hypotonic nuclei buffer (NB) (10 mM PIPES pH 7.4,

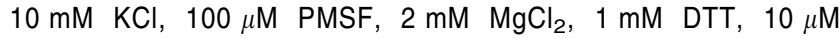
cytochalasin B). One tablet of COMPLETE ${ }^{\circledR}$ protease inhibitor (Roche, Meylan, France) was added per $20 \mathrm{ml}$ of NB. The cells were then resuspended in $10 \mathrm{vol}$ of NB, and swelled for 20 min on ice. After swelling, cells were disrupted with 20-30 strokes of a tight-fitting dounce homogenizer. Up to $2 \mathrm{ml}$ of homogenate were layered over $5 \mathrm{ml} \mathrm{NB}$ plus $30 \%$ sucrose, and centrifuged for $5 \mathrm{~min}$ at $1000 \times \mathrm{g}$. The nuclei pellet was further resuspended and washed three times in cold PBS and finally pelleted at $1000 \times g$ for $5 \mathrm{~min}$. Then nuclei were stored in $5 \mathrm{ml}$ of freezing buffer (FB) (10 mM PIPES pH 7.4, $80 \mathrm{mM} \mathrm{KCl}$, $20 \mathrm{mM} \mathrm{NaCl}, 5 \mathrm{mM}$ EGTA, $250 \mathrm{mM}$ sucrose, $500 \mu \mathrm{M}$ spermidine, $200 \mu \mathrm{M}$ spermine, $50 \%$ glycerol, $100 \mu \mathrm{M}$ PMSF, $1 \mathrm{mM}$ DTT, COMPLETE ${ }^{\circledR}$ ) at $-20^{\circ} \mathrm{C}$.

\section{Cytoplasmic extracts}

The cytoplasmic extracts were prepared as described previously. ${ }^{30,38}$ Briefly, cells were collected after treatment with trypsin-EDTA $(0.15 \%$, $0.015 \%$ respectively), washed once with cold PBS, once with extraction buffer (EB) (50 mM PIPES pH 7.4, $50 \mathrm{mM} \mathrm{KCl,} 5 \mathrm{mM}$ EGTA, $100 \mu \mathrm{M}$ PMSF, 2 mM MgCl $2,1 \mathrm{mM}$ DTT, $20 \mu \mathrm{M}$ cytochalasin
B, COMPLETE ${ }^{\mathbb{R}}$ ), resuspended in 1 vol of $E B$, and pelleted at $2000 \times g$ for 5 min directly into a dounce homogenizer. The cell pellet was resuspended in $1 \mathrm{vol}$ of $94 \%(\mathrm{v} / \mathrm{v})$ ethanol and quickly frozen at $-80^{\circ} \mathrm{C}$. The complete lysis was obtained after three cycles of freezing-thawing. After the lysate was centrifuged at $15000 \times g$ for $45 \mathrm{~min}$, the supernatant was clarified by high-speed centrifugation in a Beckman L8-70 Ultracentrifuge at $150000 \times g$ for $3 \mathrm{~h}$. The cytoplasmic extracts were stored under liquid nitrogen.

\section{Reconstituted in vitro cell-free system}

Nuclei were washed once with cold dilution buffer (DB) $(10 \mathrm{mM}$ HEPES, $40 \mathrm{mM} \beta$-glycerophosphate, $50 \mathrm{mM} \mathrm{NaCl}, 2 \mathrm{mM} \mathrm{MgCl}$, $5 \mathrm{mM}$ EGTA, $1 \mathrm{mM}$ DTT, $2 \mathrm{mM}$ ATP, $10 \mathrm{mM}$ phosphocreatine, $50 \mu \mathrm{g} /$ $\mathrm{ml}$ creatine phosphokinase), and resuspended to a final concentration of $5 \times 10^{7}$ nuclei per $\mathrm{ml}$ of $\mathrm{DB}$. The cytoplasmic fractions were diluted to a final concentration of $8 \mathrm{mg}$ of protein per $\mathrm{ml}$ of DB. Cytoplasm from non apoptotic cells supplemented or not with $200 \mathrm{nM} \mathrm{ST}$, or cytoplasm from apoptotic cells were incubated with isolated nuclei from viable cells at $4^{\circ} \mathrm{C}$, and $37^{\circ} \mathrm{C}$ for $10,20,40,50,60$ and $70 \mathrm{~min}$. Nuclei were then analyzed by flow cytometry and fluorescence microscopy. All experiments were performed at least three times.

\section{Flow cytometry analysis}

Cell cycle distribution was analyzed by flow cytometry as follows: cells were harvested by trypsinization, washed three times with cold PBS, and fixed with $70 \%(\mathrm{v} / \mathrm{v})$ cold ethanol for $1 \mathrm{~h}$ at $4^{\circ} \mathrm{C}$. After washing twice with cold PBS, $10^{6}$ cells were resuspended in $1 \mathrm{ml}$ of staining solution (PBS $1 \times, 1 \mathrm{mg} / \mathrm{ml}$ RNase A Dnase-free, $1 \mathrm{mg} / \mathrm{ml}$ propidium iodide) for $60 \mathrm{~min}$ at $4^{\circ} \mathrm{C}$. DNA content was determinated by flow cytometry using a FACS Calibur with the CellQUEST (Becton Dickinson, Heidelberg, Germany) and ModFit (Verity Software House, USA) softwares for profile analysis. For each experiment, a statistical analysis was realized with GraphPad Prism software, and results were scored to achieve statistical significance.

\section{Assessment of apoptosis}

Cell death was assessed by measuring the binding of FITC-labeled Annexin $\mathrm{V}$ protein to the phospholipid phosphatidylserine which is present on the external surface of the membrane of apoptotic cells. ${ }^{40}$ $10^{6}$ cells were stained according to the manufacturer's instructions (Annexin-V-FLUOS staining Kit, Roche). Apoptosis induction was also quantified by determining the percentage of cells with a sub-diploïd DNA content by FACS Calibur analysis. Apoptotic cell death was also studied by in situ labeling of cell preparations using terminal deoxynucleotidyl transferase and fluoresceinated dUTP (TUNEL assay). The In Situ Cell Death Detection Kit (Roche) was used according to the manufacturer's instructions.

Nuclear morphology from whole cells or isolated nuclei were also observed by fluorescence microscopy After DAPI (Sigma) nuclear staining. The analysis was performed using a Zeiss Axiophot microscope equipped with the following filter set (Excitation filter UV-G365, Chromatic division filter FT-395, Arrest filter LP-420). Images were acquired using a $\mathrm{COHU}$ camera controlled by the Cytovision Applied Imaging analysis program.

Cellular DNA from apoptotic whole cells, or from isolated nuclei of the cell-free system was extracted with chloroform/isoamyl alcohol (24/1). DNA corresponding roughly to $10^{6}$ cells was separated through a $2.5 \%$ agarose gel ( $100 \mathrm{~V}$ for $60 \mathrm{~min}$ ). After electrophoresis, gels were stained with an ethidium bromide solution $(0.5 \mu \mathrm{g} / \mathrm{ml})$, and the 
DNA fragmentation was visualized by UV light. All images were acquired using a Gel Doc 1000, and controlled by the Multi-Analyst Image Analysis Systems from Bio-Rad.

\section{Acknowledgements}

This work was supported in part by grants from Association pour la Recherche contre le Cancer (Paris) and Ligue contre le cancer (départements du Doubs et du Jura). We would like to thank respectively Agnes Lienard and Nelly Maitret for flow cytometry and fluorescence microscopy analysis. The authors thank students and all members of the laboratory for their help and encouragement during the course of this work. We are grateful to Dr. Georges Herbein for helpful comments on this manuscript.

\section{References}

1. Bosch FX, Manos MM, Munoz N, Sherman M, Jansen AM, Peto J, Schiffman MH, Moreno V, Kurman Rand Shah KV (1995) Prevalence of human papillomavirus in cervical cancer: a worldwide perspective. International Biological Study on Cervical Cancer (IBSCC) Study Group. J. Natl. Cancer Inst. 87: 796-802

2. Walboomers JMM, Jacobs MV, Manos MM, Bosch FX, Kummer JA, Shah KV, Snijders PJF, Peto J, Meijer CJLM and Munoz N (1999) Human papillomavirus is a necessary cause of invasive cervical cancer worldwide. J. Pathol. 189: 12-19

3. Wallin KL, WiklundF, Angstrom T, Bergman F, StendahIU, Wadell G, Hallmans G and Dillner J (1999) Type-specific persistence of human papillomavirus DNA before the development of invasive cervical cancer. N. Engl. J. Med. 341: 16331638

4. Banks L, Spence P, Androphy E, Hubbert N, Matlashewski G, Murray A and Crawford L (1987) Identification of human papillomavirus type 18 polypeptide in cells derived from human cervical carcinomas. J. Gen. Virol. 68: 1351-1359

5. Werness BA, Levine AJ and Howley PM (1990) Association of human papillomavirus type 16 and 18 E6-proteins with p53. Science 248: 76-79

6. Huibregtse JM, Scheffner M and Howley PM (1993) Localization of the E6-AP regions that directs human papillomavirus $\mathrm{E} 6$ binding, association with $\mathrm{p} 53$, and ubiquitination of associated proteins. Mol. Cell. Biol. 13: 4918-4927

7. Dyson N, Howley PM, Münger Kand Harlow E (1989) The human papillomavirus 16 E7 oncoprotein is able to bind the retinoblastoma gene product. Science 243 : 934-937

8. Crook T, Wrede D, Tidy JA, Mason WP, Evans DJ and Vousden KH (1992) Clonal p53 mutation in primary cervical cancer: association with human papillomavirusnegative tumors. Lancet 339: 1070-1073

9. Dulic V, Kaufmann W, Wilson S, TIsty T, Lees E, Harper J, Elledge S and Reed S (1994) p53-dependent inhibition of cyclin-dependent kinase activities in human fibroblasts during radiation-induced G1 arrest. Cell 76: 1013-1023

10. Thomas M, Pim D and Banks $L$ (1999) The role of the E6-p53 interaction in the molecular pathogenesis of HPV. Oncogene 18: 7690-7700

11. Thomas M, Matlashewski G, Pim D and Banks L (1996) Induction of apoptosis by p53 is independent of its oligomeric state and can be abolished by HPV-18 E6 through ubiquitin mediated degradation. Oncogene 13: 265-273

12. Lowe SW, Ruley HE, Jacks T and Housman DE (1993) p53-dependentapoptosis modulates the cytotoxicity of anticancer agents. Cell 74: 957-967

13. Okuda T, Sawada H, Kato Y, Yumoto Y, Ogawa K, Tashima M and Okuma M (1991) Effects of protein kinase $A$ and calcium/phospholipid-dependent kinase modulators in the process of $\mathrm{HL}-60$ cell differentiation: their opposite effects between HL-60 cell and K-562 cell differentiation. Cell Growth Differ. 2: 415-420

14. Schwartz GK, Redwood SM, Ohnuma T, Holland JK, Droller MJ and Liu BCS (1990) Inhibition of invasion of invasive human bladder carcinoma cells by protein kinase C inhibitor staurosporine. J. Natl. Cancer Inst. 82: 1753-1756

15. Bruno S, Ardelt B, Skierski JS, Traganos F and Darzynkiewicz Z (1992) Different effects of staurosporine, an inhibitor of protein kinases, on the cell cycle and chromatin structure of normal and leukemia lymphocytes. Cancer Res. 51:470473
16. Wang RH and Xue SB (1997) Staurosporine blocked normal cells at G1/S boundary. Acta. Pharmacol. Sinica. 18: 161-165

17. Abe K, Yoshida M, Usui T, Horinouchi S and Beppu T (1991) Highly synchronous culture of fibroblasts from $\mathrm{G} 2$ block caused by staurosporine, a potent inhibitor of protein kinases. Exp. Cell Res. 192: 122-127

18. Akinaga S, Nomura K, Gomi Kand Okabe M (1994) Effect of UCN-01, a selective inhibitor of protein kinase $\mathrm{C}$, on the cell cycle distribution of human epidermoid carcinoma, A431 cells. Cancer Chemother. Pharmacol. 33: 273-280

19. Crissman HA, Gadbois DM, Tobey RA and Bradbury EM (1991) Transformed mammalian cells are deficient in kinase-mediated control of progression through the G1 phase of the cell cycle. Proc. Natl. Acad. Sci. USA 88: 7580-7584

20. Solary E, Bertrand R, Kohn KW and Pommier Y (1993) Differential induction of apoptosis in undifferentiated and differentiated HL-60 cells by DNA topoisomerase I and II inhibitors. Blood 81: 1359-1368

21. Schimke RT, Kung A, Sherwood SS, Sheridan J and Sharma R (1994) Life, death and genomic change in perturbed cell cycles. Phil. Trans. R. Soc. Lond. B. 345 311-317

22. Bernhard EJ, Muschel RJ, Bakanauskas VJ and McKenna WG (1996) Reducing the radiation-induced G2 delay causes HeLa cells to undergo apoptosis instead of mitotic death. Int. J. Radiat. Biol. 69: 575-584

23. Lock RB, Thompson BS, Sullivan DM and Stribinskiene L (1997) Potentiation of etoposide-induced apoptosis by staurosporine in human tumor cells is associated with events downstream of DNA-protein complex formation. Cancer Chemother. Pharmacol. 39: 399-409

24. Lush RM, Senderowicz A, Figg WD, Headlee D, Inoue Kand Sausville EA (1997) Surprising pharmacokinetics of $\mathrm{UCN}-01$ in patients with refractory neoplasms may be due to a high degree of protein binding. Proc. Am. Ass. Cancer Res. 38: 600

25. McDonald AC, Propper D and King D (1997) Phase I and pharmacokinetic study of CGP 41251, an inhibitor of protein kinase C. Proc. Am. Soc. Clin. Oncol. 16 $212 a$

26. Martin SJ and Green DR (1995) Protease activation during apoptosis: death by a thousand cuts? Cell 82: $349-352$

27. Enari M, Hase A and Nagata S (1995) Apoptosis by a cytosolic extract from Fasactivated cells. EMBO J. 14: 5201-5208

28. Zamzami N, Susin SA, Marchetti P, Hirsch T, Gomez-Monterreyl, Castedo Mand Kroemer G (1996) Mitochondrial control of nuclear apoptosis. J. Exp. Med. 183: $1533-1544$

29. Liu X, Kim N, Yang R, Jemmerson R and Wang X (1996) Induction of apoptotic program in cell-free extracts requirement for dATP and cytochrome c. Cell 86 $147-157$

30. Lazebnik YA, Cole S, Cooke CA, Nelson WG and Earnshaw WC (1993) Nuclear events of apoptosis in vitro in cell-free mitotic extracts: a model system for analysis of the active phase of apoptosis. J. Cell Biol. 123: 7-22

31. Newmeyer DD, Farschon DM and Reed JC (1994) Cell-free apoptosis in Xenopus egg extracts: inhibition by Bcl-2 and requirement for an organelle fraction enriched in mitochondria. Cell 79: 353-364

32. Chow SC, Weis M, Kass G, Holmstrom TH, Eriksson JE and Orrenius S (1995) Involvement of multiple proteases during Fas-mediated apoptosis in $T$ lymphocytes. FEBS Lett., 364: 134-138

33. Eastman A and Rigas JR (1999) Modulation of apoptosis signaling pathways and cell cycle regulation. Semin. Oncol. 26: 7-16

34. Wyllie AH, Kerr JFR and Currie AR (1980) Cell death: the significance of apoptosis. Int. Rev. Cytol. 68: 251-305

35. Allen TD (1987) Ultrastructural aspects of cell death. In: Perspectives on mammalian cell death (Oxford: Oxford University Press) pp. 39-65

36. Kerr JFR, Searle J, Harmon BV and Bishop CJ (1987) Apoptosis. In Perspectives on mammalian cell death (Oxford: Oxford University Press) p. 93

37. Thipgen JT, Vance R, Puneky L and Khansur T (1995) Chemotherapy as a palliative treatment in carcinoma of the uterine cervix. Semin. Oncol. 22: 16-24

38. Munoz N, Bosch XM and Kaldor JM (1988) Does human papillomavirus cause cervical cancer? The state of the epidemiological evidence. Br. J. Cancer 57: 1 -

39. Reeves WC, Brinton LA, Garcia M, Brenes MM, Herrero R, Gaitan E, Tenorio F, de Britton RC and Rawls WE (1989) Human papillomavirus infection and cervical cancer in Latin America. N. Engl. J. Med. 20: 1437-1441 
40. Schiffman MH, BauerHN, Hoover RN, Glass AG, Cadell DM, Rush BB, ScottDR, Sherman ME, Kurman RJ, Wacholder S et al. (1993) Epidemiologic evidence showing that human papillomavirus infection causes mostcervical intraepithelial neoplasia. J. Natl. Cancer Inst. 85: 958-964

41. Lorincz AT, Reid R, Jenson AB, Greenberg MD, Lancaster W and Kurman RJ (1992) Human papillomavirus infection of the cervix relative risk associations of 15 common anogenital types. Obstet. Gynecol. 79: 328-337

42. Meissner JD (1999) Nucleotide sequences and further characterization of human papillomavirus DNA present in the CaSki, SiHa and HeLa cervical carcinoma cell lines. J. Gen. Virol. 80: 1725-1733

43. Vousden KH (1994) Interactions between papillomavirus proteins and tumor suppressor gene products. Adv. Cancer Res. 64: 1-24

44. Hahn WC, Counter CM, Lundberg AS, Beijersbergen RL, Brooks MW and Weinberg RA (1999) Creation of human tumour cells with defined genetic elements. Nature 400: 464-468

45. Scheffner M, MüngerK, Byrne JC and Howley PM (1991) The state of the p53 and retinoblastoma genes in human cervical carcinoma cell lines. Proc. Natl. Acad. Sci. USA 88: 5523-5527

46. Srivastava S, Tong YA, Devadas K, Zou ZQ, Chen Y, Pirollo KF and Chang EH (1992) The status of the p53 gene in human papillomavirus positive or negative cervical carcinoma cell lines. Carcinogenesis 13: 1273-1275

47. Schnier JB, Gadbois DM, Nishi K and Bradbury EM (1994) The kinase inhibitor staurosporine induces $\mathrm{G} 1$ arrest at two points: effect on retinoblastoma protein phosphorylation and cyclin-dependent kinase 2 in normal and transformed cells. Cancer Res. 54: 5959-5963

48. Kwon TK, Buchchholz MA, Chrest FJ and Nordin AA (1996) Staurosporineinduced $\mathrm{G} 1$ arrest is associated with the induction and accumulation of cyclindependent kinase inhibitors. Cell Growth Differ. 7: 1305-1313

49. Akiyama T, Yoshida T, Tsujita T, Shimizu M, Mizukami T, Okabe Mand Akinaga S (1997) G1 phase accumulation induced by UCN-01 is associated with dephosphorylation of $\mathrm{Rb}$ and $\mathrm{CDK} 2$ proteins as well as induction of $\mathrm{CDK}$ inhibitor p21/Cip1/WAF1/Sdi1 in p53-mutated human epidermoid carcinoma A431 cells. Cancer Res. 57: 1495-1501

50. Chang T, Khalsa O, Wang H, Lee ME and Schlegel R (1996) Staurosporine resistance accompanies DNA tumor virus-induced immortalization and is independent of the expression and activities of ERK1, ERK2, cyclin A, cyclindependent kinase (cdk) 2 and cdk4. Cell Growth Differ. 7: 361-372

51. Usuda J, Saijo N, Fukuoka K, Fukumoto H, Kuy HJ, Nakamura T, Koh Y, Suzuki T, Koizumi F, Tamura T, Kato H and Nishio K (2000) Molecular determinants of UCN-01-induced growth inhibition in human lung cancer cells. Int. J. Cancer 85 $275-280$

52. Traganos F, Gong J, ArdeltB and DarzynkiewiczZ (1994) Effect of staurosporine on MOLT-4 cell progression through G2 and on cytokinesis. J. Cell Physiol. 158: $535-544$

53. Akiyama T, Shimizu M, Okabe M, Tamaoki T and Akinaga S (1999) Differential effects of UCN-01, staurosporine and CGP 41251 on cell cycle progression and $\mathrm{CDC2} /$ Cyclin $\mathrm{B} 1$ regulation in $\mathrm{A} 431$ cells synchronized at $M$ phase by nocodazole. Anticancer drugs 10: 67-78
54. Tam SW and Schlegel R (1992) Staurosporine overrides checkpoints for mitotic onset in BHK cells. Cell Growth Differ. 3: 811-817

55. Lohka MJ and Masui $Y$ (1983) Formation in vitro of sperm pronuclei and mitotic chromosomes induced by amphibian ooplasmic components. Science 220: $719-721$

56. Murray AW and Kirschner MW (1989) Cyclin synthesis drives the early embryonic cell cycle. Nature 339: 275-280

57. Krude T, Jackman M, Pines J and Laskey RA (1997) Cyclin/Cdk-dependent initiation of DNA replication in a human cell-free system. Cell 88: 109-119

58. Dao T, Huleatt JW, Hingorani R and Crispe IN (1997) Specific resistance of T cells to CD95-induced apoptosis during S phase of the cell cycle. J. Immunol. 159: $4261-4267$

59. Hengstschläger M, Hölzl G and Hengstschläger-Ottnad E (1999) Different regulation of c-Myc-and E2F-1-induced apoptosis during the ongoing cell cycle. Oncogene 18: 843-848

60. Nakajima H, Golstein P and Henkart PA (1995) The target cell nucleus is not required for cell-mediated granzyme or Fas-based cytotoxicity. J. Exp. Med. 181: $1905-1909$

61. Jacobson MD, Burne JF and Raff MC (1994) Programmed cell death and Bcl-2 protection in the absence of a nucleus. EMBO J. 13: 1899-1910

62. Schulze-OsthoffK, Walczak H, Droge Wand KrammerH (1994)Cell nucleus and DNA fragmentation are not required for apoptosis. J. Cell Biol. 127: 15-20

63. Bertrand R, Solary E, O'ConnorP, Kohn KW and Pommier Y (1994) Induction of a common pathway of apoptosis by staurosporine. Exp. Cell Res. 211: 314-321

64. El-Deiry WS, Harper JW, O'Connor PM, Velculescu VE, Canman CE, Jackman J, Pietenpol JA, Burrell M, Hill DE, Wang Y, Wiman KG, Mercer WE, Kastan MB, Kohn KW, Flledge SJ, Kinzler KW and Vogelstein B. (1994) WAF1/CIP1 is induced in p53-mediated G1 arrest and apoptosis. Cancer Res. 54:1169-1174

65. Cross SM, Sanchez CA, Morgan CA, Schimke MK, Ramel S, Idzerda RL, Raskind WH and Reid BJ (1995) A p53-dependent mouse spindle checkpoint. Science 267: 1353-1356

66. Bunz F, Dutriaux A, Lengauer C, Waldman T, Zhou S, Brown JP, Sedivy JM, Kinzler KW and Vogelstein B (1998) Requirement for p53 and p21 to sustain G2 arrest After DNA damage. Science 282: 1497-1500

67. Clarke AR, Purdie CA, Harrison DJ, Morris RG, Bird CC, Hooper ML and Wyllie AH (1993) Thymocyte apoptosis induced by p53-dependent and independent pathways. Nature 362: $849-852$

68. Funaoka K, Shindoh M, Yamashita T, Fujinaga K, Amamiya A and Totsuka $Y$ (1996) High-risk HPV-positive human cancer cell lines show different sensitivity to cisplatin-induced apoptosis correlated with the $\mathrm{p} 21^{\text {Waf1/Cip } 1}$ level. Cancer Lett. 108: 15-23

69. Butz K, Geisen C, Ullmann A, Spitkovsky D and Hoppe-Seyler F (1996) Cellular responses of HPV-positive cancer cells to genotoxic anti-cancer agents: repression of E6/E7-oncogene expression and induction of apoptosis. Int. J. Cancer 68: 506-513

70. Sugikawa E, Hosoi T, Yazaki N, Gamanuma M, Nakanishi N and Ohashi M (1999) Mutant p53 mediated induction of cell cycle arrest and apoptosis at G1 phase by 9-hydroxyellipticine. Anticancer Res. 19: 3099-3108 